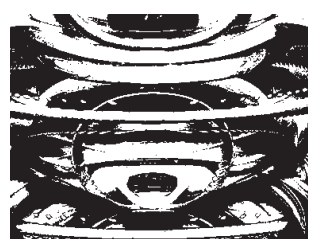

\title{
DVIJE PARADIGME OBJASSNJENJA KOGNITIVNIH PRISTRANOSTI U ODLUČIVANJU: "BIHEVIORALNA EKONOMIJA" I "EKOLOŠKA RACIONALNOST"
}

Darko POLŠEK

Filozofski fakultet, Zagreb

Marko BOKULIĆ

Sveučiliše u Regensburgu, Regensburg

UDK: 330.8:159.9.019.4

Stručni rad

Primlieno: 18. 10. 2012.

U ovom radu autori navode temeline ideje dvaju smjerova ili paradigmi istraživanja na području tzv. bihevioralne ekonomije, odnosno istraživanja heuristika i pristranosti. Prva je paradigma (bihevioralna ekonomija) proizašla iz empirijskih nalaza koji su proturječili modelima teorije racionalnog odlučivanja "klasične" ekonomije. Autori pobliže opisuju teoriju racionalnog odlučivanja (TRO) kako bi pokazali osnovne empirijske nalaze i postavke "bihevioralnih ekonomista", ponajprije nobelovca D. Kahnemana i A. Tverskog, prema kojima su liudi iracionalni kada se "u uvjetima ograničene racionalnosti" služe predvidliivim i vrlo tipičnim pristranostima, odnosno kada se "odmiču" od normi racionalnosti utvrđenih u TRO. Druga paradigma istraživanja heuristika i pristranosti, G. Gigerenzera i njegovih suradnika, pokazuje kako su ljudi opremljeni dovoljno dobrim sredstvima (heuristikama) za brzo i jednostavno odlučivanje, ali dokazuje da se pogreške u odlučivanju, za razliku od tvrdnji bihevioralnih ekonomista, ne pojavljuju zbog "nedovolinog razmišljanja" i pogrešnoga procesuiranja nego zbog pogrešne primjene danih mentalnih sposobnosti (heuristika) u neadekvatnim situacijama.

Ključne riječi: bihevioralna ekonomija, heuristike, pristranosti, brze-i-štedlijve heuristike, Kahneman, Tversky, Gigerenzer 


\section{"ŠTO JE BIHEVIORALNA EKONOMIJA"}

Prema uvriježenoj definiciji bihevioralne ekonomije, riječ je o disciplini koja objašnjavalačku snagu ekonomije pojačava realističnijim psihološkim, socijalnim i emocionalnim faktorima u razumijevanju ekonomskih i, općenito, životnih odluka pojedinaca i institucija (Camerer i Loewenstein, 2004). Granice ljudske racionalnosti koje ispituje bihevioralna ekonomija odnose se na tržišne odluke, ali i na sva druga područja odlučivanja: u politici, medicini i svakodnevnom životu. Kako je riječ o vrlo obuhvatnoj definiciji, bihevioralna je ekonomija tek jedno od prihvaćenih imena za spektar činjenica i teorija vrlo širokoga dosega. Činjenice koje tvore temelj objašnjavalačkih teorija dio su i brojnih drugih disciplina, poput "bihevioralnih financija", kognitivne i socijalne psihologije, sociologije, politologije, kognitivne antropologije ili, u novije doba, primjerice tzv. "neuroekonomije". A kako se uzroci "iracionalnosti" ljudskoga postupanja često traže i u evolucijskoj teoriji, psihološkim mehanizmima ili neuralnim procesima, neki teoretičari tvrde da bi bihevioralna ekonomija trebala postati "okvir za objedinjavanje svih bihevioralnih znanosti" (Gintis, 2007).

Bihevioralna je ekonomija, dakle, ime za disciplinu koja se bavi procesima odlučivanja stvarnih ljudi. Ti procesi stoga moraju odražavati ljudska ograničenja: manjkavosti u znanju, dostupnom vremenu ili kognitivnim sposobnostima za donošenje idealne odluke. Takav okvir istraživanja zovemo i pristupom "ograničene racionalnosti" (eng. bounded rationality), racionalnosti koja se - za razliku od modela racionalnosti "klasične" ekonomije, prema kojima vremenska, informacijska i druga ograničenja nisu bitni faktori za predviđanje ljudskog ponašanja - promatra $u$ realističnim uvjetima za donošenje odluke.

Da bismo procijenili važnost istraživanja bihevioralnih ekonomista i njihovih teorija, moramo najprije postaviti pitanje: o kakvim je to racionalnim modelima ponašanja riječ, odnosno mogu li klasični ekonomistički modeli racionalnosti biti uspješni u predviđanju ljudskih postupaka?

\section{KLASIČNI MODEL EKONOMSKE RACIONALNOSTI}

"Klasična" je ekonomija ponudila matematički jednostavne i sveobuhvatne modele ljudskog odlučivanja. Oni pretpostavljaju da osobe uvijek odabiru najbolju ili "optimalnu" opciju, izbor koji najbolje zadovoljava subjektove preferencije (Hausman, 2008). Prema tim modelima, ljudi su "mehanički" maksimalizatori dobiti. Oni se rukovode načelima "bolje je više nego manje", ako je riječ o dobitima, odnosno "bolje je manje nego više", ako je riječ o kaznama. Ljudske preferencije prema tim modelima moraju zadovoljavati neke elementarne logičke kri- 
DRUŠ. ISTRAŽ. ZAGREB GOD. 22 (2013), BR. 2 STR. 303-323

POLŠEK, D., BOKULIĆ, M. DVIJE PARADIGME... terije, poput tranzitivnosti. Ako osoba preferira A, umjesto B, a $B$ umjesto $C$, onda bi logično morala preferirati $A$ a ne $C$. Racionalnost u klasičnom smislu temelji se na postavkama koje bi "svatko racionalan" morao prihvatiti.

Preferencije u "klasičnoj" ekonomiji tipično su biheviorističke: o njima se ne sudi na temelju neke "dubinske psihologije" nego (novčanom ili nekom drugom) kvantifikacijom motivacija, preferencija, izbora i strateških odluka (Frank, 1991, 2008). Tako je po mnogima nastala karikatura - redukcionističko shvaćanje čovjeka kao da je "homo economicus". Najbolju formulaciju "homo economicusa" dao je John Stuart Mill (1836): "Ekonomija se ne bavi svim aspektima ljudske prirode ... Ona se čovjekom bavi isključivo kao bićem koje želi posjedovati bogatstvo i koje je sposobno procijeniti i usporediti učinkovitost pojedinih sredstava za zadovoljavanje nekog cilja." Međutim, upravo je takva redukcija želja na samo one materijalne bila instrumentalna $\mathrm{u}$ izvođenju preciznih predviđanja o tome kako bi racionalna osoba trebala odlučivati.

"Klasična" ekonomistička koncepcija racionalnosti oblikuje se teorijom racionalnog izbora (TRI), koju su prvi skicirali von Neumann i Morgenstern (1944). Prema tim autorima, racionalnost se može modelirati maksimalizacijom očekivane dobiti. Svaka je opcija svojevrsna lutrija (ili oklada), koju razlažemo na ishode i s njima povezane vjerojatnosti. Svi su izbori "kockarske igre" u kojima više ili manje poznajemo relevantne vjerojatnosti ishoda, odnosno cijene i isplate. Dobit čak i ne mora biti isključivo materijalna: bitno je da ne bude neka nemjerljiva "psihička tvar" (Elster, 2007). Maksimalizacija očekivane dobiti odnosi se na pretpostavku da ljudi biraju opciju koja najčešće vodi do najboljeg ispunjenja subjektovih želja. TRI pretpostavlja da ljudi biraju najbolju ponuđenu opciju, a to je po mnogima posve nerealistična pretpostavka, ali joj je upravo ona omogućila da postane provjerljiva deskriptivna i normativna teorija. Ako se pokaže da ljudi ne donose odluke u skladu sa TRI (tj. ako ona zakaže kao deskriptivna teorija), njihovo ponašanje možemo "popraviti" upozoravanjem na najracionalniju ponuđenu opciju.

Za potpunu racionalnost, međutim, racionalna bi potom trebala biti i vjerovanja, način prikupljanja informacija i zaključivanje (Elster, 2007). "Sastojci" potrebni za donošenje racionalnog izbora jesu vjerovanja, opcije, ishodi i vjerojatnosti. Primjerice, pri odlučivanju bismo li sutra otišli na planinarenje ili ostali kod kuće, važno je prognozirati vrijeme, a za to nam je potrebno znanje o vremenskim prilikama iz prošlosti i znanje o tome kako te podatke obraditi. Razni modeli stoga opisuju optimalno uloženo vrijeme u takvu obradbu (i ostale, tzv. oportunitetne troškove) prije donošenja odluke, ali trošak pretrage ili izračunavanja ne smije biti veći od dobitka (Elster, 
DRUŠ. ISTRAŽ. ZAGREB GOD. 22 (2013), BR. 2, STR. 303-323

POLŠEK, D., BOKULIĆ, M.: DVIJE PARADIGME...
2007). Naposljetku, TRI pretpostavlja da ljudi barataju temeljnim statističkim konceptima za procjenu vjerojatnosti raznih ishoda, primjerice pravilima statističkog uzorkovanja i Bayesijanskim pravilima za zaključivanje o vjerojatnostima (Camerer i Loewenstein, 2004).

U slučaju tzv. strateških odluka, kada je riječ o odlukama koje ovise i o drugim subjektima ili "igračima" ili sukcesivnim stanjima, situacija je tek neznatno teža. Tzv. teorija igara jedna je od varijanti TRI, u kojoj, osim vlastite hijerarhije preferencija, u model racionalnog odlučivanja ubacujemo i hijerarhiju preferencija drugih osoba. Isto tako, u teorijama vremenskoga diskontiranja klasični ekonomisti opisuju kako vrijednost nekoga dobra raste ili pada ovisno o vremenskoj udaljenosti za njegovu konzumaciju. Prema tom modelu, primjerice, ljudi bi $100 \mathrm{kn}$ radije dobili danas negoli sutra (Frederick, Loewenstein i O'Donoghue, 2004).

TRI i teoriji igara nije bila potrebna neka dodatna "psihologija". Najbolje je objašnjenje ujedno i ono najjednostavnije. Ljudi će birati sredstva kojima će "najjeftinije", "optimalno" ostvariti svoje ciljeve, tj. ako je omjer njihovih dobiti i troškova "isplativ".

Jednostavnost "klasičnih" ekonomističkih modela racionalnosti bila je i prednost za bihevioralne ekonomiste, koji su u modele racionalnosti počeli "ubacivati dodatnu psihologiju". "Ekonomija se od drugih društvenih znanosti razlikuje po uvjerenju da se većina (sva?) ljudska ponašanja mogu objasniti pretpostavkom da subjekti imaju stabilne, dobro definirane preferencije, a njih naposljetku dokazuju racionalni izbori konzistentni s tim izborima na tržištu" (Kahneman, Knetsch i Thaler, 1991).

Ekonomisti vjeruju (ili su do pojave bihevioralnih ekonomista vjerovali) kako takva ideja racionalnosti (teorija očekivane dobiti homo economicusa) dovoljno dobro funkcionira i kao objašnjenje empirijskih činjenica. Ako je netko izgubio na lutriji, to je zbog toga što je krivo procijenio vjerojatnost dobitka ili se poveo za svojim emocijama. Uspjeh ili neuspjeh pojedinca (i kolektiva) tako je jednak zbroju pametnih ili loših odluka, pa ćemo uspješne pojedince moći zvati racionalnima, a neuspješne neracionalnima. Ekonomisti su pretpostavljali da se ljudi najčešće doista i rukovode takvom normom racionalnosti te da je TRI i valjana deskriptiona teorija ljudskoga ponašanja (Friedman, 1953; prema Hausman, 2008).

Pokazalo se, međutim, da su "klasični" ekonomski modeli imali neke nerealistične postavke: pretpostavke o "nadljudskim" sposobnostima rezoniranja, o golemoj količini vremena za donošenje odluke ili o potpunosti dostupnih informacija. Velik broj empirijskih rezultata doveo je u sumnju empirijsku adekvatnost TRI. Povjerenje u TRI bilo je (i ostalo) tako jako 
DRUŠ. ISTRAŽ. ZAGREB GOD. 22 (2013), BR. 2 STR. $303-323$

POLŠEK, D., BOKULIĆ, M. DVIJE PARADIGME..

da su se bihevioralni nalazi katkada smatrali pukim "anomalijama" (Kahneman i sur., 1991). Premda se "klasični" model racionalnosti pokazao empirijski neadekvatnim, jer se ljudi kao što znamo - $\mathrm{u}$ brojnim situacijama ne ponašaju racionalno, on je u povijesti društvenih znanosti imao (i još uvijek ima) veliku ulogu. Za razliku od lutajuće empirije drugih društveno-znanstvenih, bihevioralnih disciplina, takva empirijski neadekvatna teorija kao norma racionalnosti pružila je barem "mjerilo" racionalnosti odluka, pa se njezino značenje ne treba zanemariti.

\section{NOVA PARADIGMA - "ODMAK OD NORMI": PRISTUP "HEURISTIKA I PRISTRANOSTI"}

Snaga "logičnih" modela i predviđanja stvorila je još jednu posljedicu: sada se i odmak od "racionalnih" predviđanja mogao matematički mjeriti.

Razmotrimo jedan jednostavan primjer vrlo životne situacije u kojoj je primjena TRI toliko složena da je ljudi s pravom odbacuju. Treba li se ženiti? Prema TRI, da bismo izračunali osobnu očekivanu korist od braka, trebali bismo odrediti sve moguće posljedice braka, potom bismo svakoj od tih posljedica trebali pridodati kvantitativne vjerojatnosti, procijeniti subjektivnu korist svake posljedice, pomnožiti svaku korist i njoj pridruženu vjerojatnost i naposljetku zbrojiti sve te brojeve. Isti postupak trebali bismo ponoviti i za alternativnu opciju "ne ženiti se". Za takav izračun morali bismo investirati godine razmišljanja, a to smo vrijeme mogli korisnije utrošiti na neke druge pothvate. A kada bismo partneru rekli kako smo "kalkulantski" došli do te odluke, nije sigurno da bi brak opstao (Gigerenzer, 2007; Gigerenzer i Brighton, 2009).

Ovakvo intuitivno odbacivanje TRI teorijski, međutim, nije dovoljno prihvatljivo. Prvi koraci bihevioralnih ekonomista bili su dokazi o postojanju "paradoksa" u TRI. Primjerice, Allaisov paradoks (Allais, 1953) pokazuje kako tipično kršimo "aksiom neovisnosti", prema kojemu se naš izbor dviju opcija ne bi trebao mijenjati ako svakoj opciji dodamo ili oduzmemo istu vrijednost, odnosno ako je zbroj dobiti i šansi u obje varijante izbora jednak. Zamislimo dvije nagradne igre. U prvoj igri izbor nam je sljedeći: (1A) da dobijemo milijun dolara sigurno, ili (1B), tj. (a) milijun dolara sa $89 \%$ šanse i (b) $1 \%$ da ne dobijemo ništa i (c) $10 \%$ šanse da dobijemo 5 milijuna dolara. Allaisovi ispitanici, kao i brojni drugi u ponovljenom eksperimentu, češće su odabirali prvu opciju - opciju sigurnosti. U drugoj igri ispitanicima nudimo sljedeće - analogne - isplate. U prvoj varijanti (2A) da dobijemo milijun dolara sa $11 \%$ šansi i ništa sa $89 \%$ šansi; a u drugoj (2B) da dobijemo pet milijuna dolara sa $10 \%$ šansi i ništa sa $90 \%$ šansi. Sada, kada obje opci- 
DRUŠ. ISTRAŽ. ZAGREB GOD. 22 (2013), BR. 2, STR. 303-323

POLŠEK, D., BOKULIĆ, M.: DVIJE PARADIGME... rijantu (2B) i time krše aksiom neovisnosti. Slično je bilo i s tzv. "Ellsbergovim paradoksom", koji je dokazao ljudsku averziju prema neizvjesnosti i time kršio načelo ravnodušnosti. Ako ispitanike suočite s izborom (A) "U boci je 50 crnih i 50 bijelih loptica. Ako izvučete crnu lopticu, dobit ćete 100 dolara", odnosno (B) "U boci je nepoznat broj crnih i bijelih loptica. Ako izvučete crnu, dobit ćete 100 dolara", većina ispitanika bira opciju (A), premda nam TRI kaže da su opcije jednake te da bismo prema njima trebali biti ravnodušni.

Rani bihevioralni ekonomisti (Coase, Allais, Simon) pokazali su također da se pri donošenju odluka mora ukalkulirati vrijeme. Je li korisnije dalje tražiti informacije ili odmah donijeti odluku? U stvarnim uvjetima odlučivanja nije jasno što je "objektivni" optimum, a što su procjene troškova i dobiti, pa čak ni kako bismo u spomenutoj dvojbi trebali oblikovati njihovu normu oblikovanja. Autor koncepta "ograničene racionalnosti", Herbert Simon (1990), tvrdio je, primjerice, kako se ljudi najčešće rukovode načelom "zadovoljenja": "kada odlučuješ o ponuđenim opcijama, kreni s prvim dovoljno dobrim rješenjem na koje naiđeš".

Camerer i Loewenstein (2004) opisali su "recept" za tipično bihevioralno-ekonomsko istraživanje. Najprije utvrdi ishode prema klasičnoj normativnoj TRI. Potom empirijski dokaži postojanje anomalija - odnosno tipičnih ponašanja koja se ne mogu objasniti klasičnim normama. Naposljetku, iskoristi utvrđene anomalije kao inspiracije za nove teorije i modele.

U provođenju bihevioralno ekonomističkog istraživačkog programa najveću su ulogu imali psiholozi Daniel Kahneman i Amos Tversky (Tversky i Kahneman, 1982). Njihovi jednostavni eksperimenti bili su revolucionarni u istraživanju odlučivanja stvarnih subjekata jer su pokazali da ljudi standardno - predvidljivo - griješe u odlučivanju. Oni su pokazali da u uvjetima neizvjesnosti (a stvarne su odluke gotovo uvijek takve) ljudi donose pogrešne odluke čak i kada su im pružene sve informacije. Oni su dokazali da su racionalne sposobnosti laika, ali i stručnjaka (Englich i Mussweiler, 2001; McNeil, Pauker, Sox i Tversky, 1982), u procjeni i izračunu vjerojatnosti događaja vrlo skromne i da bitno odudaraju od pretpostavki klasičnih teorija racionalnosti. Međutim, vrijednost njihovih istraživanja i eksperimenata bila je još i veća kada se iz ponovljenih eksperimenata pokazalo da su te ljudske neracionalnosti odlučivanja - predvidljive.

Ako traganje za informacijama proizvodi trošak, ljudi će biti prisiljeni smisliti načine, "trikove", kratice, metode za "skraćenje" postupaka pri odlučivanju, odnosno za pronalaženje informacija kako bi uštedjeli na vremenu. Te "metode" danas zovemo heuristikama. Temeljni zaključak programa istraživanja "heuristika i pristranosti" Kahnemana i Tverskog bio je da 
DRUŠ. ISTRAŽ. ZAGREB GOD. 22 (2013), BR. 2 STR. 303-323

POLŠEK, D., BOKULIĆ, M.: DVIJE PARADIGME... se ljudi, ograničeni svojim kognitivnim sposobnostima i znanjem, u razmišljanju služe "prečicama" ili heuristikama, ali da nas upravo one navode na pogrešne (ili pristrane) odluke i zaključke (Gilovich, Griffin i Kahneman, 2002).

Zamislimo da vas ispitivač zamoli da procijenite je li (u opisanoj skupini od 70 inženjera i 30 pravnika) Josip inženjer ili pravnik: "Josip ima 30 godina. Oženjen je i nema djecu. Kao čovjek visokih sposobnosti i visoke motivacije, on ima šanse postati vrlo uspješan na svojem području. Kolege ga jako vole." Da nismo imali Josipov opis, vjerojatno bismo razmotrili početne omjere inženjera i pravnika u uzorku i zaključili kako je vjerojatnost da je Josip inženjer 70\%, odnosno da je 30\% šansi da je on pravnik. Ali uz posve neinformativan Josipov opis, zbog "viška informacija", mi tipično počinjemo razmišljati uklapa li se Josipov opis u stereotip pravnika ili inženjera, i tada pogrešno zaključujemo kako je Josip "vjerojatnije" pravnik. Na sličnim eksperimentima pokazalo se da su ljudi skloniji temeljiti procjenu vjerojatnosti na sličnosti (usporedbom sa stereotipom) negoli na razmatranju statističkih načela. Ljudi zapravo početne distribucije uzorka i ne uzimaju u obzir, nego se tipično oslanjaju na to koliko je Josipov opis reprezentativan za pravnike, odnosno inženjere. Heuristika reprezentativnosti stoga nas često navodi na pogrešne zaključke i odluke; ona je toliko "jaka" da zbog nje u pravilu zanemarujemo mnogo relevantnije ili racionalnije načine donošenja odluka.

Kahneman i Tversky pokazali su kako postoje brojne slične heuristike. U drugim se testovima procjena sličnosti ne oslanja na stereotip ili prosjek populacije nego na ideju o tipičnom ishodu nekoga slučajnog procesa. Je li, primjerice, vjerojatniji niz u bacanju novčića "PPPGGG" ili "PGPPGG" (Tversky i Kahneman, 1982)? Većina ljudi kaže kako je vjerojatnija druga opcija. A ako prvi niz zamijenimo nizom "PPPPPG"? Tada pogotovo. Mi tipično rabimo tzv. "kockarsku" pogrešku, jer očekujemo da će se nizovi "ispraviti".

Sličnim eksperimentom, tzv. "problemom Linde", Kahneman i Tversky pokazali su kako pod utjecajem irelevantnih i suvišnih opisa ljudi krše jednostavne logičke zakone (pogreška konjunkcije).

Kahneman i Tversky svojim su eksperimentima pobijali i drugu stranu mita o racionalnosti čovjeka, naime o njegovu racionalnom izboru. Ljudi nemaju stabilne preferencije, neovisne o kontekstu u kojem se ispituju, nego u raznim situacijama donose nesukladne izbore (Kahneman i Tversky, 1984). TRI, primjerice, tvrdi da na preferencije ne bi trebale utjecati irelevantne razlike opisa, "konteksta" ili "prikaza situacije". U slavnom primjeru koji pobija ovo pravilo, problemu "Azijske bolesti", ispitanike se tražilo da zamisle epidemijsku situaciju u kojoj je zaraženo 600 ljudi. Koji bi tretman smatrali poželjni- 
DRUŠ. ISTRAŽ. ZAGREB GOD. 22 (2013), BR. 2, STR. 303-323

POLŠEK, D., BOKULIĆ, M.: DVIJE PARADIGME... jim: tretman A, koji sigurno spašava 200 ljudi, ili tretman B, koji je riskantniji i po kojem postoji $1 / 3$ vjerojatnosti da se spase svi, odnosno $2 / 3$ vjerojatnosti da se neće spasiti nitko. Premda su izbori matematički identični, većina ljudi izabire opciju A. Međutim, kada se drugoj skupini ispitanika postavio isti problem, samo što su ishodi predstavljeni kao gubici, većina ispitanika birala je riskantniju opciju B' (1/3 vjerojatnosti da nitko ne umre, $2 / 3$ da umru svi zaraženi) od sigurnije situacije A' u kojoj bi preminulo 400 ljudi. McNeil i suradnici (1982) dokazali su isti obrat preferencija na primjeru (fiktivnog) izbora između operacije i radijacijske terapije raka pluća. Ispitanici su bili mnogo skloniji odabrati opciju s pozitivnim šansama (90\% uspjeha) negoli s negativnom vjerojatnosti (šansa smrti 10\%). To pak znači da naši odabiri čak i u vrlo životnim situacijama tipično ovise o tome kako nam netko formulira pitanje. Zanimljivo je da se spomenuti nalaz nije promijenio ni kada se isto pitanje postavilo liječnicima. Bihevioralnim ekonomistima činjenica da eksperti pokazuju iste iracionalnosti kao i laici, međutim, nije iznenađujuća (vidi: Englich i Mussweiler, 2001 za studiju pravnika, te Tversky i Kahneman 1971 za eksperte u statistici).

Ovakva istraživanja dovela su do triju bitnih preinaka TRI. Kahneman i Tversky pokazali su: 1) da su ljudi u matematički (ili statistički) identičnim situacijama bitno skloniji donijeti odluku sa sigurnim ishodima negoli s "vjerojatnostima" i 2) da postoji bitna asimetrija pozitivnih i negativnih prikaza istih situacija: ljudi su mnogo skloniji izvjesnosti (sigurnosti) kada je riječ o dobicima, odnosno mnogo skloniji rizicima kada im se situacija prikazuje kao gubitak. (O trećoj preinaci vidi niže.) Dobitak od 100 kn donosi razmjerno manju ugodu od štete koju doživljavamo kada izgubimo 100 kn. Tu asimetriju danas zovemo "teorijom perspektive" (engl. Prospect Theory) (Kahneman i Tversky, 1984). Nadalje, pokazalo se da su ljudi osjetljiviji na promjene stanja negoli na ukupne promjene bogatstva. I napokon, ljudi ne doživljavaju na isti način sve identične razlike vjerojatnosti. Primjerice, porast vjerojatnosti sa $0 \%$ na $5 \%$ čini nam se mnogo "važnijim" i većim negoli porast sa 30 na $35 \%$, premda se radi o identičnom povećanju. Sličnu nelinearnost doživljavamo i na drugom kraju spektra, prilikom skoka iz nesigurnosti u sigurnost (npr. s prelaskom vjerojatnosti iz $95 \%$ na 100\%). I tu se količina promjene znatno precjenjuje $u$ odnosu na identične razlike $u$ sredini spektra. Ljudi tipično precjenjuju male vjerojatnosti (npr. vrijednost dobitka na lotu pri vrlo maloj vjerojatnosti), odnosno kada skaču iz nesigurnosti u sigurnost (primjerice, kada tipično preplaćuju osiguranje koje pokriva "sve").

Posebnu vrstu pogrešaka činimo kada odlučujemo na temelju nedavnih istaknutih ili pogubnih događaja ili kada ne- 
DRUŠ. ISTRAŽ. ZAGREB GOD. 22 (2013), BR. 2 STR. 303-323

POLŠEK, D., BOKULIĆ, M.: DVIJE PARADIGME.. što lakše prizivamo u pamćenje. Tada nam se čini da su one vjerojatnije od drugih. Pokažemo li ispitanicima niz slika s većim brojem poznatih žena (premda je broj prikazanih muškaraca i žena isti), ispitanici će reći da u prikazanom skupu ima više žena. Ako je nedavno u vašem susjedstvu bio požar (ili ste o tome jučer čitali u novinama), ispitanici će prosuđivati da su požari vjerojatniji negoli što doista jesu. Pokažemo li ispitanicima niz brojeva od 10 do 1 i upitamo li ih da brzo procijene kolik je njihov umnožak, a ako drugu skupinu upitamo da to učini s nizovima od 1 do 10 , odgovori tih skupina bitno će se razlikovati - prosudbe druge skupine bit će bitno manje (a obje će skupine bitno podcijeniti točan rezultat). To je zbog toga što prva skupina kreće u izračun s prvim, većim, brojevima, a druga s manjima (svakoj su skupini "dostupniji" različiti prvi brojevi). Takve, i brojne slične, pogreške Kahneman i Tversky zovu pogreškama (odnosno heuristikom) dostupnosti.

Možda je najzanimljivija treća vrsta pogrešaka - pogreška "sidrenja". To je pogreška pri kojoj odgovore na pitanja nesvjesno prilagođujemo nekom prethodno proizvoljno ponuđenom "sidru". Kahneman i Tversky proveli su eksperiment u kojem su ispitanicima najprije okrenuli "kolo sreće" (od 1 do 100). Potom su im postavili pitanje: "Je li broj afričkih zemalja u Ujedinjenim narodima veći ili manji od broja koji ste dobili? Treba li ga povećati ili smanjiti?" Dobiveni broj na kolu sreće značajno će utjecati na vaše procjene broja afričkih zemalja u $\mathrm{UN}-\mathrm{u}$ (za detaljniji prikaz istraživanja sidrenja vidi: Bokulić i Polšek, 2010).

Kahneman i Tversky eksperimentalno su pokazali i niz drugih efekata koje su isprva klasificirali u spomenute tri "heuristike i pristranosti". Primjerice, u nizu sličnih događaja zanemarujemo statističku tendenciju regresije prema srednjoj vrijednosti i ne prepoznajemo situacije u kojima se ona pojavljuje; vjerujemo da veća odstupanja od srednje vrijednosti nalazimo na većem uzorku, skloni smo precjenjivati ponovljivost rezultata dobivenih na malim uzorcima (posebno u uvjetima selekcijskih zadataka), za primjercima iz većeg uzorka obično brže i lakše posežemo negoli za primjercima manje frekventne klase, vjerojatnije pojave lakše zamišljamo negoli nevjerojatnije, asocijativnu povezanost događaja pojačavamo tako da radimo pogrešku "iluzorne korelacije", stvaramo bitno različite numeričke procjene, ovisno o zamišljenim ili istaknutim početnim vrijednostima (nedovoljno podešavamo procjene).

Istraživanja koja su uslijedila utvrdila su pedesetak sličnih "pristranosti", koje nastaju kad se ljudi služe svojstvenim prečicama ili heuristikama. Primjerice, više nam "vrijedi" objekt koji posjedujemo nego što bismo za nj željeli platiti (Kahneman i sur., 1991). Više "vrijedi" 100 kn danas negoli obećanje 
DRUŠ. ISTRAŽ. ZAGREB GOD. 22 (2013), BR. 2, STR. 303-323

POLŠEK, D., BOKULIĆ, M.: DVIJE PARADIGME... da ćemo istu svotu dobiti za mjesec dana. Premda znamo da su nam prijašnje odluke bile pogrešne te da smo uzalud potrošili novac, radije se odlučujemo za nastavak ulaganja u promašeni projekt nego da ga odbacimo i krenemo s novim. Tipično podcjenjujemo vrijeme koje je potrebno za dovršenje zadatka. U složenim izborima češće se opredjeljujemo za to da ne donosimo nikakve odluke itd.

Zanimljivost bihevioralno-ekonomskih istraživanja i njihove "paradigme" jest u predvidljivosti naših pogrešaka. To pak znači da se ne možemo zadovoljiti konstatacijom kako "ljudi naprosto griješe" u prosudbama. Naime, ako je riječ o pogreškama kojima je podložna većina ljudi (ispitanika), treba potražiti njihove dublje ili zajedničke uzroke. Ako postoje razlozi ili mehanizmi zbog kojih ljudi predvidljivo donose pogrešne odluke, postavlja se nekoliko važnih pitanja. Prvo: zašto su te "pogreške" standardne (odnosno zašto im je podložna većina). I drugo, kakav je status ekonomističkih "racionalnih" normi, ako se većina ljudi njima uopće ne rukovodi. Možda je najvažnije pitanje oblikovanje neke objedinjavajuće teorije koja će objasniti cijeli spektar spomenutih (i nespomenutih) pristranosti. Vrlo je jasno da su heuristike Kahnemana i Tverskog tek provizorne kategorije ili ladice za klasifikaciju efekata te da ne nude neko "objašnjavalačko obećanje" za pronalaženje fundamentalnijih mehanizama koji stvaraju spomenute efekte.

Pri odgovorima na ova pitanja istraživači pristranosti krenuli su različitim putovima. Prva skupina istraživača (tzv. "bihevioralni ekonomisti") i dalje traži objašnjenja u okvirima "odmaka" od pretpostavljenih normi racionalnosti. Njih uglavnom više zanimaju sami efekti i začudnost eksperimentalnih nalaza negoli objedinjavajuća, teorijska objašnjenja. Kako kažu Camerer i Loewenstein (2004), opisujući stanje u literaturi o preferencijama: "popis promašaja neke teorije nije alternativna teorija". Usmjerenost na odmake od normi, tj. na pristranosti, za ovaj je pristup trebala biti samo metoda dolaženja do kognitivnih procesa (heuristika). Međutim, "metoda je postala važan dio poruke" (Tversky i Kahneman, 1982), što je naišlo na oštre kritike.

Druga skupina istraživača potražila je pak odgovore na postavljena pitanja u posve drugom sklopu normi, na području "urođenosti" koje nam je pružila evolucija. Tu drugu skupinu istraživača heuristike zanimaju kao "adaptivna oruđa", koja izvrsno funkcioniraju u stvarnome svijetu. Ti istraživači opisane nalaze neće zvati "pogreškama" i pristranostima nego pogrešnom primjenom heurističkih alata u neprimjerenim situacijama. 


\section{DRUGA PARADIGMA: EVOLUCIJSKA PSIHOLOGIJA I MODEL "EKOLOŠKE RACIONALNOSTI"}

Program bihevioralnih ekonomista pretpostavlja da su ljudi predvidljivo iracionalni. Istraživačka skupina pod vodstvom Gerda Gigerenzera, međutim, tvrdi da je ljudsko rezoniranje zadovoljavajuće - pod uvjetom da ga proučavamo u kontekstu u kojem se mišljenje i razvijalo, odnosno u kojima ljudi obično donose procjene (Gigerenzer, Todd i ABC Research Group, 1999). Ljudima je svojstvena ekološka racionalnost, a ne racionalnost koja se definira apstraktnim i o kontekstu neovisnim normama (Gigerenzer, 1996). Naše su heuristike specifične za pojedine domene, stoga je ovaj pristup u skladu s temeljnom tezom o modularnosti evolucijske psihologije, prema kojoj su sve naše adaptacije evoluirale zbog rješavanja specifičnih "životno važnih" problema.

Kako je čovjekov okoliš uvijek u nekoj mjeri predvidljiv, ljudi se mogu služiti jednostavnim metodama procjene koje iskorištavaju tu predvidljivost. Herbert Simon (1990) predložio je da se ljudsko razmišljanje usporedi sa škarama: jedna oštrica predstavlja strukturu okoliša, a druga kognitivne sposobnosti osobe. Funkcioniranje škara nećemo shvatiti ako ne razumijemo obje oštrice. Ljudsku racionalnost, prema ovoj paradigmi, nema smisla proučavati $\mathrm{u}$ apstraktnim zadacima i očekivati da će se na njih preslikati efikasnost razmišljanja prilagođena nekom drugom okolišu. Navedeni razlozi - poštivanje realnih uvjeta i ljudskih ograničenja - doveli su do pristupa tzv. "brzih i štedljivih" heuristika (eng. fast and frugal heuristics; Gigerenzer i sur., 1999). Ove su heuristike jednostavne u proračunima, a "štedljive" su po tome što ne zahtijevaju mnogo informacija za donošenje odluke. Ova obitelj heuristika ima dvije namjene: prvo, objasniti kako ljudi doista donose odluke (slično kao i Kahneman i Tversky), i drugo, istražiti kako se može unaprijediti donošenje odluka. Potonji cilj posebno iznenađuje, jer su heuristike iz ove paradigme toliko jednostavne da je teško shvatiti kako bi se one, po racionalnosti, mogle uspoređivati s kompleksnim statističkim metodama kao "zlatnim standardom" za donošenje procjena. Slogan istraživačkoga programa i modela ekološke racionalnosti glasi "Manje je više".

Pristup ekološke racionalnosti ne odbacuje klasične ekonomske i bihevioralno-ekonomske modele samo zbog neadekvatnosti u objašnjenju stvarnih ljudskih ponašanja; on poriče i njihovu normativnost. Empirijsku neadekvatnost klasičnih modela poriču i bihevioralni ekonomisti. Ali pristup "ekološke racionalnosti" tvrdi nešto jače: naime, da je paradigma bihevioralne ekonomije tek naličje one klasične, jer bez nje bihevioralna ekonomija ne može utvrditi da je neka odluka pristrana ili neracionalna. 
DRUŠ. ISTRAŽ. ZAGREB GOD. 22 (2013), BR. 2, STR. 303-323

POLŠEK, D., BOKULIĆ, M.: DVIJE PARADIGME...
Glavnina kritika na račun "bihevioralne ekonomije" usredotočuje se na tvrdnju da su eksperimentalni postavi klasične i bihevioralne ekonomije stvoreni kako bi "zavarali" ispitanike, odnosno kako bi zavarali naše prirođene ili urođene tendencije prilikom razmišljanja i donošenja odluka. Oni umjetno mijenjaju okoliš ili kontekst odlučivanja kojem su namijenjene pojedine heuristike. Primjerice, $\mathrm{u}$ standardnoj logici i $\mathrm{u}$ TRI poredak konjunktivnih sudova ne mijenja logičku funkciju složenoga suda $(A \& B)=(B \& A)$. Naše prirodno adaptivno oruđe, međutim, barata drukčijom heuristikom. Primjerice: poredak sudova "Josip i Vesna su se oženili" i "Josip i Vesna su dobili dijete" ima bitno drukčiji smisao od poretka "Josip i Vesna su dobili dijete" i "Josip i Vesna su se oženili". Naš um sadrži heuristiku koja poredak sudova "čita" kauzalno: u prvom je slučaju riječ o "prirodnom redu stvari", a izvrnuti poredak sudova čitamo kao da je riječ o "prisilnoj ženidbi". Isto tako u "Linda eksperimentu" (i u drugim eksperimentima s "viškom informacija") ispitanici se rukovode heuristikom relevantnosti: ljudi prirodno pretpostavljaju da im sugovornici ne pružaju besmislene informacije, stoga je logično da rade "pogrešku konjunkcije". Naš um nije evoluirao za baratanje apstraktnim logičkim operatorima, nego se logičke operacije supsumiraju pod "jače" - evolucijsko načelo. Poput Wasonova eksperimenta: mi bitno bolje rješavamo Wasonov zadatak ${ }^{1} u$ modulu "pronalaženja krivca" negoli kao apstraktan zadatak pronalaženja pravilnosti slova i brojki na kartama. Naša se logička sposobnost odlučivanja derivira iz evolucijski dizajniranoga zadatka, stoga je "logično" da ćemo evolucijski primjeren zadatak rješavati bitno bolje od "apstraktnoga". Glavni je cilj bihevioralnih ekonomista bio dokaz da ljudi nisu dovoljno racionalni, umjesto da su se usredotočili na analizu heuristika, odnosno na odgovor zašto i kako one funkcioniraju.

Skupina s Instituta Max Planck u Berlinu proslavila se eksperimentima kojima je dokazivala da neznatno poboljšana heuristika zadovoljenja Herberta Simona (donesi odluku čim ti se pruži opcija iznad prethodno postavljene razine aspiracija), odnosno vrlo jednostavna leksikografska heuristika "take-the-best", ili uzmi-najboljega, može pobijediti kompleksne metodologije u brojnim situacijama za koje nam je inače ("racionalno") potrebna razmjerno složena statistička aparatura. Njihova najpoznatija heuristika "uzmi najboljega" (TTB) sastoji se od poretka kriterija za odluku, od binarne procjene prema kriteriju i od pravila da se prestane s pretragom informacija (odnosno s donošenjem odluke) u trenutku kada jednu alternativu prepoznajemo kao bolju u ponuđenoj ili pretpostavljenoj hijerarhiji kriterija. U koju ćemo školu upisati dijete? Ako nam je hijerarhija relevantnih kriterija (poput abecednoga niza) broj učenika, kvaliteta nastavnika, broj učionica itd., 
DRUŠ. ISTRAŽ. ZAGREB GOD. 22 (2013), BR. 2 STR. 303-323

POLŠEK, D., BOKULIĆ, M.: DVIJE PARADIGME... i ako ne možemo donijeti odluku na temelju prvoga kriterija jer su mogućnosti iste (poput prvoga slova u riječima "Ande" i "antilopa"), krećemo na drugi kriterij (drugo slovo u riječi). Čim kriterij dovoljno razlikuje ponuđene opcije, treba zaustaviti pretragu i donijeti odluku (kvaliteta nastavnika u školi A je bolja - zaustavi pretragu i upiši dijete u školu s boljom kvalitetom nastavnika).

Kakav je doseg "brzih i štedljivih" heuristika u usporedbi s kompleksnijim i komputacijski zahtjevnijim statističkim metodama? Czerlinski, Gigerenzer i Goldstein (1999) usporedili su ove dvije vrste pristupa u računalnoj simulaciji na čak 20 setova podataka. Gigerenzer i suradnici zagovaraju metodološko načelo formuliranja heuristika kao komputacijskih modela, načelo koje se prethodno rijetko provodilo. Heuristike ovih autora jasno specificiraju kako se pretražuju informacije (ponajprije - kada stati s pretragom) i kako se informacije agregiraju u konačne odluke. "Je li grad A veći od grada B?" Heuristika TTB odgovara na temelju poznavanja poretka prediktora po valjanosti. Primjerice, ako želimo predvidjeti koji je grad veći, najbolje nam je pogledati je li jedan od njih glavni grad (Gigerenzer i Goldstein, 1999). Ako nije, tj. ako najbolji prediktor ne diskriminira te dvije opcije, prijeđi na sljedeći najbolji prediktor. TTB, dakle, odgovara načelu "brzih i štedljivih" heuristika. Ona je jednostavna jer zahtijeva isključivo poznavanje poretka prediktora po njihovoj prognostičkoj valjanosti ("abecedu"). Ne zahtijeva mnogo informacija, jer ćemo procjenu često moći donijeti na temelju samo jednoga prediktora, zbog čega se i brzo provodi. "Protivnik" TTB-a bila je linearna regresija, predstavnik statističkih modela, koja se služi mnogo većim brojem podataka. Ona uzima apsolutnu vrijednost prediktora (tj. njihovu točnost, a ne samo njihov poredak) te njihove međusobne povezanosti i na temelju ovih podataka izračunava optimalan zbroj prediktivnih varijabli, tako da svaka od tih varijabli u regresijskoj jednadžbi dobije svoje optimalno opterećenje (ponder). Osim što je kompleksna, ova metoda podrazumijeva da se za svaku pojedinu procjenu uzimaju svi podaci koji su na raspolaganju. Czerlinski i suradnici (1999) sukobili su linearnu regresiju i TTB u računalnoj simulaciji predviđanja. Uspješnost se ispitala tako da su se uzorci podataka podijelili na dva dijela: onaj za "učenje" i onaj za predviđanje. Na setu za učenje bili su poznati podaci za prediktore i za kriterij, pa su obje metode mogle preuzeti podatke koji im trebaju za kalkulaciju. Set za predikciju koristio se tim podacima kako bi iz poznatih prediktora predvidio nepoznati kriterij. Računalna je simulacija, dakle, bila apstrakcija onoga što nam se događa u stvarnom životu: na temelju poznatih relacija donosimo zaključke o onima nepoznatima. Iako se jednostavnija heuristika "uzmi najboljeg" 
DRUŠ. ISTRAŽ. ZAGREB GOD. 22 (2013), BR. 2, STR. 303-323

POLŠEK, D., BOKULIĆ, M.: DVIJE PARÁDIGME...

(1) TABLICA 1

Gigerenzerova sistematika heuristika služila manjim brojem podataka i jednostavnijim načelom donošenja procjene, ona je točnije predviđala ishode.

Dokazivanjem da je naša prirodna racionalnost dovoljno dobra da u predviđanjima i izborima pobijedi čak i sofisticirane statističke metode, da je "manje često bolje" te tvrdnjama da ljudi nisu tako iracionalni kako tvrde bihevioralni ekonomisti, u kasnijim su radovima Gigerenzer i njegova skupina (Gigerenzer i Brighton, 2009) popisu bihevioralno-ekonomskih "pogrešaka" ili pristranosti suprotstavili deset temeljnih i vrlo prilagodljivih heuristika, koje možemo rabiti i koje i rabimo u raznim domenama. Riječ je o sljedećim heuristikama:

\begin{tabular}{|c|c|c|c|}
\hline Heuristike & Definicija & Ekološki racionalna & Začudni nalazi \\
\hline $\begin{array}{l}\text { Heuristika } \\
\text { prepoznavanja }\end{array}$ & $\begin{array}{l}\text { Ako se prepoznaje jedna } \\
\text { od mogućnosti, pretpostavi } \\
\text { da ima višu vrijednost } \\
\text { prema kriteriju. }\end{array}$ & Ako je valjanost $>.5$ & $\begin{array}{l}\text { Manje je više ako A > B; sistemat- } \\
\text { ski zaborav može biti koristan. }\end{array}$ \\
\hline $\begin{array}{l}\text { Heuristika } \\
\text { "fluentnosti" }\end{array}$ & $\begin{array}{l}\text { Ako se prepoznaju obje mo- } \\
\text { gućnosti, ali jednu prepozna- } \\
\text { jemo brže, zaključi da ona } \\
\text { ima višu vrijednost prema } \\
\text { kriteriju. }\end{array}$ & $\begin{array}{l}\text { Ako je valjanost } \\
\text { fluentnosti }>.5\end{array}$ & $\begin{array}{l}\text { Efekt manje je više; sistematsko } \\
\text { zaboravljanje je korisno. }\end{array}$ \\
\hline $\begin{array}{l}\text { Uzmi-najboljega } \\
\text { (Gigerenzer- } \\
\text {-Goldstein) }\end{array}$ & $\begin{array}{l}\text { Da zaključiš koja mogućnost } \\
\text { ima višu vrijednost: A) pre- } \\
\text { traži ključeve prema redosli- } \\
\text { jedu valjanosti, B) prestani } \\
\text { pretraživati čim ključ diskri- } \\
\text { minira, C) izaberi moguć- } \\
\text { nost koju favorizira ključ. }\end{array}$ & & $\begin{array}{l}\text { Često predviđa bolje od multiple } \\
\text { regresije, neuralne mreže, eg- } \\
\text { zemplarni modeli, algoritmi sta- } \\
\text { bla odlučivanja. }\end{array}$ \\
\hline $\begin{array}{l}\text { Ponderiranje } \\
\text { (jedinično, } \\
\text { linearno) } \\
\text { (Dawes) }\end{array}$ & $\begin{array}{l}\text { Za procjenu kriterija ne } \\
\text { procjenjuj pondere, nego } \\
\text { jednostavno izbroji niz } \\
\text { pozitivnih ključeva. }\end{array}$ & $\begin{array}{l}\text { Mala varijabilnost } \\
\text { pondera, mala } \\
\text { redundantnost. }\end{array}$ & $\begin{array}{l}\text { Često predviđa jednako točno } \\
\text { kao i višestruka regresija. }\end{array}$ \\
\hline $\begin{array}{l}\text { Zadovoljenje } \\
\text { (Simon, Todd, } \\
\text { Miller) }\end{array}$ & $\begin{array}{l}\text { Pretraži mogućnosti i } \\
\text { izaberi prvu koja nadilazi } \\
\text { tvoju razinu aspiracija. }\end{array}$ & $\begin{array}{l}\text { Broj mogućnosti naglo } \\
\text { pada s vremenom, kao } \\
\text { u slučaju s potencijalnim } \\
\text { fondom partnera. }\end{array}$ & $\begin{array}{l}\text { Aspiracijske razine dovode do } \\
\text { značajno boljih izbora od } \\
\text { slučajnih, premda su arbitrarni. }\end{array}$ \\
\hline $\begin{array}{l}\text { 1/N heuristika } \\
\text { jednakosti } \\
\text { (De Miguel) }\end{array}$ & $\begin{array}{l}\text { Alociraj resurse jednako } \\
\text { preko N mogućnosti. }\end{array}$ & $\begin{array}{l}\text { Visoka nepredvidljivost, } \\
\text { mali uzorak za učenje, } \\
\text { velik N. }\end{array}$ & $\begin{array}{l}\text { Često superiornija od "optimal- } \\
\text { nih" uloga (portfolija). }\end{array}$ \\
\hline $\begin{array}{l}\text { Heuristika "stan- } \\
\text { darda" (Johnson- } \\
\text {-Goldstein) }\end{array}$ & $\begin{array}{l}\text { Ako postoji "standard", ne } \\
\text { čini ništa. }\end{array}$ & $\begin{array}{l}\text { Vrijednosti onih koji po- } \\
\text { stavljaju standard pokla- } \\
\text { paju se s donositeljem } \\
\text { odluke; kada je posljedice } \\
\text { izbora teško predvidjeti. }\end{array}$ & $\begin{array}{l}\text { Objašnjava zašto pozivi imaju } \\
\text { malen učinak na registraciju } \\
\text { donatora organa, predviđa po- } \\
\text { našanje kada teorije obilježja i } \\
\text { preferencija to ne mogu. }\end{array}$ \\
\hline $\begin{array}{l}\text { Milo-za-drago } \\
\text { (Axelrod) }\end{array}$ & $\begin{array}{l}\text { Prvo surađuj, potom } \\
\text { oponašaj prethodno } \\
\text { ponašanje partnera. }\end{array}$ & $\begin{array}{l}\text { Drugi igrači igraju isto } \\
\text { TFT, pravila igre dopu- } \\
\text { štaju prijevaru i suradnju, } \\
\text { ali ne i razgradnju igre. }\end{array}$ & $\begin{array}{l}\text { Može dovesti do više isplate od } \\
\text { optimalizacije (indukcija } \\
\text { unatrag). }\end{array}$ \\
\hline \multicolumn{4}{|c|}{ (nastavak na sljedećoj stranici) } \\
\hline
\end{tabular}




\begin{tabular}{llll}
\hline Heuristike & Definicija & Ekološki racionalna & Začudni nalazi \\
\hline $\begin{array}{l}\text { Oponašaj većinu } \\
\text { (Boyd-Richerson) }\end{array}$ & $\begin{array}{l}\text { Razmotri većinu u vla- } \\
\text { stitoj skupini, a potom } \\
\text { oponašaj njihovo ponašanje. }\end{array}$ & $\begin{array}{l}\text { Okolina je stabilna ili se } \\
\text { sporo mijenja; pretraga } \\
\text { informacija je skupa i } \\
\text { vremenski zahtjevna. }\end{array}$ & $\begin{array}{l}\text { Glavna snaga u oblikovanju } \\
\text { parova, skupnoj identifikaciji i } \\
\text { moralnom ponašanju. }\end{array}$ \\
$\begin{array}{l}\text { Oponašaj } \\
\text { uspješnoga }\end{array}$ & $\begin{array}{l}\text { Razmotri najuspješniju } \\
\text { osobu i oponašaj njegovo/ } \\
\text { njezino ponašanje. }\end{array}$ & $\begin{array}{l}\text { Individualno je učenje } \\
\text { sporo, pretraga informacija } \\
\text { skupa i vremenski zahtjevna. }\end{array}$ & $\begin{array}{l}\text { Glavna sila u kulturnoj } \\
\text { evolui. }\end{array}$ \\
\hline
\end{tabular}

(Iz: G. Gigerenzer, H. Brighton, 2009)

(1) TABLICA 1

(Nastavak s prethodne stranice)
Program ekološke racionalnosti zamišlja ljudski um kao "kutiju s alatom" ili kao švicarski nož, tj. kao niz "dovoljno dobrih" oruđa za primjenu u većini životnih situacija. Svaka od tih oštrica (heuristika) može se izraditi bolje. Ali svaka se oštrica, isto tako, može upotrijebiti i u pogrešne svrhe. Nedvojbeno je, međutim, da prirodno raspolažemo razmjerno malom količinom heuristika za potencijalno beskonačan broj raznolikih i problematičnih situacija. Jasno je da nas neki od spomenutih alata mogu prevariti i da ih možemo upotrijebiti (i često ih upotrebljavamo) $\mathrm{u}$ neprimjerenim situacijama. Unatoč tome, doprinos Gerda Gigerenzera i njegovih suradnika pružio nam je realističnu sliku uma, koji u mnogim situacijama, s minimalnim sredstvima i minimumom utrošenog vremena, može donijeti i bolje odluke od vrlo sofisticiranih. Je li onda primjereno ljude smatrati iracionalnim ili "suboptimalnim" maksimalizatorima sebičnih interesa, kako to čine bihevioralni ekonomisti?

\section{POMIRENJE PARADIGMI?}

Jedna mogućnost "pomirenja" spomenutih paradigmi objašnjenja pristranosti mogla bi biti tzv. "teorija dvostrukoga procesuiranja". Kahneman (2002; vidi i Sloman, 2002) u svojem je nobelovskom govoru ponudio perspektivu koja se danas zove "teorija dvostrukoga procesuiranja" (za pregled vidi Chaiken i Trope, 1999). Prema toj teoriji, naš se kognitivni aparat sastoji od dvaju sustava. Prvi sustav proizlazi iz načina percipiranja stvarnosti - on je brz, paralelan, automatski, dok je drugi sustav (mišljenje) spor, naporan i serijski. Međutim, osim percepcije i mišljenja, postoji i "treći" sustav, koji skraćeno zovemo intuicijom. On s percepcijom dijeli način procesuiranja, ali s mišljenjem dijeli sadržaje koji se oblikuju u odluci. Intuicije su, slično perceptima, brze i automatske, no sadržaji intuitivnog procesuiranja nisu samo podražaji nego i apstraktni koncepti. Mišljenje pak nadgleda i eventualno prepravlja produkte intuicija, no zdrav razum i istraživanja kazuju nam da većina onoga što kažemo ili napravimo nije detaljno promišljena. Shematizam načina procesuiranja mogli bismo izložiti ovako: 


\begin{tabular}{llll}
\hline & Percepcija (sustav 1) & Intuicija & Mišljenje (sustav 2) \\
\hline \multirow{2}{*}{ Procesi } & Brzi & Spor \\
& & Paralelni & Serijski \\
& & Automatski & Kontrolirani \\
& & Bez napora & Naporni \\
& & Asocijativni & Rukovođeni pravilima \\
& & Sporo uče & Fleksibilni \\
\multirow{4}{*}{ Sadržaji } & Emocionalni & Neutralni \\
& Percepti & & Konceptualne reprezentacije \\
& Trenutačna stimulacija & Prošlost, sadašnjost i budućnost \\
& Vezani za stimuluse & Mogu se zazvati jezikom
\end{tabular}

(Prema: Kahneman, D. 2002; Sloman, S. A. 2002; Varijanta iste tablice u: T. Wilson 2004, 49.)

(1) TABLICA 2

Shematizam teorije dvostrukog procesuiranja
Osim relativno "grube" formulacije (Kahneman, 2011), čini se da ovaj - inače prihvatljiv - okvir paradigmatske sinteze nije dovoljno dobar $\mathrm{u}$ teorijsko-predviđalačkoj ulozi. Stoga nije realno očekivati da će on u budućnosti biti dovoljno snažan oblik suradnje znanstvenika koji se kreću u spomenutim suprotstavljenim paradigmama.

\section{ZAKLJUČAK - LJEPOTA HEURISTIČKE ZNANOSTI}

Današnje stanje na području ispitivanja ljudske racionalnosti vidimo kao "zlatno doba", u kojemu se novi, često iznenađujući, rezultati i modeli pojavljuju svakodnevno. Istodobno, tu novu disciplinu potresaju bitni "paradigmatski" sukobi, poput spomenutoga u tekstu - između pristupa koji ističe nedostatke ljudskog razmišljanja (Gilovich i sur., 2002) i onoga koji ističe njegovu funkcionalnost (Gigerenzer i sur., 1999). Rješenje kontroverzi i budući napredak na području bihevioralne ekonomije vrlo su važne i zanimljive teme: riječ je, naime, o sporu oko prirode i dosega ljudske racionalnosti. Odgovori na ta pitanja mogli bi nam dati upute za postupanje i odlučivanje $u$ svakodnevnim situacijama u kojima se služimo "ograničenom racionalnošću", primjerice u situacijama poput Thalerove: "kako odrediti mjesečne budžete za hranu, odjeću i ostalo?"; vidi Thaler, 2004) ili pri odlučivanju o načinu rada i kompetentnosti eksperata ("možemo li vjerovati da su presude koje se određuju u sudskim postupcima donesene samo pod utjecajem informacija relevantnih za slučaj?"; vidi Englich i Mussweiler, 2001). Odgovori koje nam nudi znanost o ljudskom odlučivanju i procjenjivanju imaju goleme posljedice za naše stavove o sebi kao prirodnoj i kulturnoj vrsti (vidi Stanovich, 2004) i na načine organizacije života (primjerice, na političke smjernice koje predlažu Thaler i Sunstein, 2008).

Čini se da je ljepota ispitivanja heuristika u tome što ni- 
DRUŠ. ISTRAŽ. ZAGREB GOD. 22 (2013), BR. 2 STR. 303-323

POLŠEK, D., BOKULIĆ, M. DVIJE PARADIGME... znanja ili više znanja, više razmišljanja ili manje razmišljanja. Zasad nema obuhvatne teorije koja će nam unaprijed reći u kojim uvjetima treba rabiti brze i jednostavne heuristike, odnosno sve raspoložive informacije. Za istraživače heuristika stvar je isto tako neizvjesna: bi li heuristički rezultati s nogometnim klubovima na temelju heuristike prepoznavanja gradova bili identični da smo ispitanike, primjerice, pitali za rukometne gradove?2 I premda očito postoje pravilnosti, situacije u kojima češće griješimo, odnosno situacije u kojima s manje znanja donosimo bolje odluke, čak i za najbolje istraživače ostaju neistražene, pa zbog toga i "lijepa" pitanja: "što bi se dogodilo da smo neznatno promijenili uvjete ispitivanja? Bi li naši rezultati unatoč tome ostali isti?" Tipičan i optimističan odgovor na ta pitanja jest: ne znamo dok ne ispitamo i tu varijantu.

Međutim, upravo obilježje koje ovo područje čini živim i zanimljivim jest i jedan od njegovih glavnih problema. Naime, do sada nije utvrđena sveobuhvatnija teorija kojom bismo objasnili čitav raspon ljudskog razmišljanja i utvrđenih pristranosti (Krueger i Funder, 2004). Pristup koji se vjerojatno najviše približio tom opisu jest teorija dvostrukoga procesuiranja, no ta je teorija vjerojatno tek okvir za objedinjavanje sadašnjih rezultata. Ta nam teorija ne govori u kojim bismo se uvjetima trebali koristiti intuicijama, odnosno svjesnim razmišljanjem; ona nam isto tako ne kaže u kojim će uvjetima jedan pristup biti bolji od drugoga. Istraživači se dosad nisu dovoljno bavili odgovorima na takva pitanja, jer su ih više zanimala mišljenja ispitanika u laboratoriju, koja su dokazivala sramotne pogreške u našem razmišljanju (Krueger i Funder, 2004). Ovo je vjerojatno bilo korisno za popularizaciju, ali područje je sada empirijski dovoljno zrelo za pravi teoretski rad. U potrazi za potpunijim modelom ne pomaže nam ni razjedinjenost literature ni "blokovska" podjela istraživača (npr. vidi raspravu Kahneman i Tversky, 1996, te Gigerenzer, 1996).

Neovisno o tome hoćemo li ikada dobiti "sveobuhvatnu" teoriju o ljudskim pristranostima, nije posve jasno hoćemo li ikada dobiti konačne odgovore čak i na ona posve obična pitanja: u kojim se situacijama isplati primijeniti pojedine heuristike i kolika je vjerojatnost pogreške prilikom njihove upotrebe $\mathrm{u}$ takvoj situaciji. Unatoč tomu, niz eksperimenata iz bihevioralne ekonomije već je sada pružio neizmjerno obilje vrlo zanimljivih nalaza o ljudskom ponašanju. Potraga za filozofskim, "konačnim" objašnjenjima našeg uma, za bihevioralne ekonomiste bit će tek eventualna sporedna premija. Kao i svim pravim znanstvenicima, fascinacija raznolikošću eksperimentalnih nalaza o tako važnome predmetu kao što je ljudska iracionalnost bihevioralnim će ekonomistima uvijek biti primarna. 


\section{BILJEŠKE}

1 Wasonov selekcijski zadatak jest slavni eksperiment o deduktivnom razmišljanju koji dokazuje da subjekti bitno bolje rješavaju (logički identičan) zadatak ako je oblikovan kao problem iz socijalne okoline (tipično: kao problem pronalaženja krivca). Vidi: Wason 1966 i en.wikipedia.org/wiki/Wason_selection task.

2 Goldstein i Gigerenzer (Gigerenzer i sur., 1999, str. 50-52) opisuju eksperiment $\mathrm{u}$ kojem se ispitanici koriste heuristikom prepoznavanja, tj. prepoznavanjem gradova, da odrede postoji li u tome gradu (poznati) nogometni klub. U spomenutome slučaju "zaključak" iz prepoznavanja grada na postojanje nogometnoga kluba funkcionira, ali on ne bi funkcionirao da je iz prepoznavanja gradova trebalo odrediti postoji li u prepoznatom (njemačkom) gradu poznati rukometni klub.

\section{LITERATURA}

Allais, M. (1953). Le comportement de l'homme rationnel devant le risque: critique des postulats et axiomes de l'école Américaine. Econometrica, 21(4), 503-546

Bokulić, M. i Polšek, D. (2010). Heuristika sidrenja. Prolegomena, 9(1), 71-95.

Camerer, C. F. i Loewenstein, G. (2004). Behavioral economics: Past, present and future. U C. F. Camerer, G. Loewenstein i M. Rabin (Ur.). Advances in behavioral economics (str. 3-53). Princeton: Princeton University Press.

Chaiken, S. i Trope, Y. (Ur.) (1999). Dual-process theories in social psychology. New York: Guilford Press.

Czerlinski, J., Gigerenzer, G. i Goldstein, D. G. (1999). How good are simple heuristics? U G. Gigerenzer, P. M. Todd i ABC Research Group (Ur.), Simple heuristics that make us smart (str. 97-118). New York: Oxford University Press.

Elster, J. (2007). Explaining social behavior: More nuts and bolts for the social sciences. Cambridge: Cambridge University Press. doi:10.1017/CB O9780511806421

Englich, B. i Mussweiler, T. (2001). Sentencing under uncertainty: Anchoring effects in the courtroom. Journal of Applied Social Psychology, 31(7), 1535-1551. doi:10.1111/j.1559-1816.2001.tb02687.x

Frank, R. H. (1991). Microeconomics and behavior. New York: McGraw Hill.

Frank, R. H. (2008). The economic naturalist: Why economics explains almost everything. London: Virgin.

Frederick, S., Loewenstein, G. i O’Donoghue, T. (2004). Time discounting and time preference: A critical review. U C. F. Camerer, G. Loewenstein i M. Rabin (Ur.), Advances in behavioral economics. Princeton: Princeton University Press.

Friedman, M. (1953). Essays in positive economics. Chicago: University of Chicago Press. 
DRUŠ. ISTRAŽ. ZAGREB GOD. 22 (2013), BR. 2, STR. 303-323

POLŠEK, D., BOKULIĆ, M.: DVIJE PARADIGME...
Gigerenzer, G. (1996). On narrow norms and vague heuristics: A reply to Kahneman and Tversky (1996). Psychological Review, 10(3), 592-596.

Gigerenzer, G. i Goldstein, D. G. (1999). Betting on one good reason: The take the best heuristic. U G. Gigerenzer, P. M. Todd i ABC Research Group (Ur.), Simple heuristics that make us smart (str. 75-97). New York: Oxford University Press.

Gigerenzer, G., Todd, P. M. i ABC Research Group (1999). Simple heuristics that make us smart. New York: Oxford University Press.

Gigerenzer. G. (2007). Gut feeling. The intelligence of the unconscious. New York: Viking.

Gigerenzer, G. i Brighton, H. (2009). Homo heuristicus: Why biased minds make better inferences. Topics in Cognitive Science, 1(1), 107-143. doi:10.1111/j.1756-8765.2008.01006.x

Gilovich, T., Griffin, D. i Kahneman, D. (2002). Heuristics and biases: The psychology of intuitive judgment. Cambridge: Cambridge University Press. doi:10.1017/CBO9780511808098

Gintis, H. (2007). A framework for the unification of the behavioral sciences. Behavioral and Brain Sciences, 30(1), 1-16. doi:10.1017/S01405 25X07000581

Hausman, D. M. (2008). Philosophy of economics. U E. N. Zalta (Ur.), The Stanford Encyclopedia of Philosophy (Fall 2008 Edition). Dostupno na http://plato.stanford.edu/archives/fall2008/entries/economics/

Kahneman, D., Knetsch, J. L. i Thaler, R. (1991). The endowment effect, loss aversion, and status quo bias. Journal of Economic Perspectives, 5(1), 193-206.

Kahneman, D. (2002). Maps of bounded rationality: A perspective on intuitive judgment and choice. Nobel Prize Lecture. Dostupno na http:// nobelprize.org/nobel_prizes/economics/laureates/2002/kahnemannlecture.pdf

Kahneman, D. (2011). Thinking fast and slow. New York: Farrar, Straus and Giroux.

Kahneman, D. i Tversky, A. (1984). Choices, values, and frames. American Psychologist, 39(4), 341-350. doi:10.1037/0003-066X.39.4.341

Kahneman, D. i Tversky, A. (1996). On the reality of cognitive illusions. Psychological Review, 103(3), 582-591. doi:10.1037//0033-295X.103. 3.582

Krueger, J. I. i Funder, D. C. (2004). Towards a balanced social psychology: Causes, consequences, and cures for the problem-seeking approach to social behavior and cognition. The Behavioral and Brain Sciences, 27(3), 313-327. doi:10.1017/S0140525X04000081

McNeil, B. J., Pauker, S. G., Sox, H. C. i Tversky, A. (1982). On the elicitation of preferences for alternative therapies. New England Journal of Medicine, 306, 1259-1262. doi:10.1056/NEJM198205273062103

Mill, J. S. (1836). On the definition of political economy, and on the method of investigation proper to it. London and Westminster Review, October. Essays on some unsettled questions of political economy, 2nd ed. London: Longmans, Green, Reader \& Dyer, 1874, essay 5.

Simon, H. A. (1990). Invariants of human behavior. Annual Review of Psychology, 41, 1-20. doi:10.1146/annurev.ps.41.020190.000245 
DRUŠ. ISTRAŽ. ZAGREB GOD. 22 (2013), BR. 2, STR. 303-323

POLŠEK, D., BOKULIĆ, M.: DVIJE PARADIGME...
Sloman, S. A. (2002). Two systems of reasoning. U T. Gilovich, D. Grifin i D. Kahneman (Ur.), Heuristics and biases (str. 379-396). New York: Cambridge University Press.

Stanovich, K. E. (2004). The robot's rebellion: Finding meaning in the age of Darwin. Chicago: University Of Chicago Press.

Thaler, R. H. (2004). Mental accounting matters. U C. F. Camerer, G. Loewenstein i M. Rabin (Ur.), Advances in behavioral economics (str. 75-104). Princeton: Princeton University Press.

Thaler, R. H. i Sunstein, C. R. (2008). Nudge: Improving decisions about health, wealth, and happiness. London: Penguin.

Tversky, A. i Kahneman, D. (1971). Belief in the law of small numbers. Psychological Bulletin, 76(2), 105-110. doi:10.1037/h0031322

Tversky, A. i Kahneman, D. (1982). Judgment under uncertainty: Heuristics and biases. U D. Kahneman, P. Slovic i A. Tversky (Ur.), Judgment under uncertainty: Heuristics and biases (str. 3-23). Cambridge: Cambridge University Press.

Von Neumann, J. i Morgenstern, O. (1944). Theory of games and economic behavior. Princeton, NJ: Princeton University Press.

Wason, P. C. (1966). Reasoning. U B. M. Foss (Ur.), New horizons in psychology. Harmondsworth: Penguin.

Wilson, T. D. (2004). Strangers to ourselves. Discovering the adaptive unconscious. Cambridge Mass.: Belknap.

\section{Two Paradigms Explaining Cognitive Bias in Decision-Making: "Behavioral Economics" and "Ecological Rationality"}

Darko POLŠEK

Faculty of Humanities and Social Sciences, Zagreb

Marko BOKULIĆ

University of Regensburg, Regensburg

In this paper the authors review a variety of empirical findings, research directions and tenets of two paradigms in heuristics and bias research: of behavioral economics (following Kahneman and Tversky's findings), and of the "less-is-more", i.e. ecological rationality research (which follows findings by G. Gigerenzer). While explaining empirical research in behavioral economics (BE), the authors describe a "classical economic" model of rationality, the rational choice theory, which is contradicted by results in behavioral economics. BE researchers use rational choice theory as a norm, so their findings are typically explained or documented by "insufficient adjustment" to, or by a bias from the rational norm. The second paradigm, however, 
DRUŠ. ISTRAŽ. ZAGREB GOD. 22 (2013), BR. 2, STR. 303-323

POLŠEK, D., BOKULIĆ, M.: DVIJE PARADIGME... typically documents "sufficiently good" decisions made while using "simple, frugal and smart" heuristics, such as "take-the-best". It claims that "irrationality" in decision-making stems from the inappropriate application of the given heuristics in ecologically unsuitable situations.

Keywords: behavioral economics, heuristics, bias, fast-and-frugal heuristics, Kahneman, Tversky, Gigerenzer 